\title{
ChAd0x1 nCov-19 vaccine-induced thrombotic thrombocytopenic purpura successfully treated with plasmapheresis
}

\author{
Yen-Ching Wang ${ }^{1} \cdot$ Tsung-Chih Chen $^{1,2} \cdot$ Chieh-Lin Jerry Teng ${ }^{1,3,4,5} \cdot$ Cheng-Han Wu ${ }^{1}$
}

Received: 28 September 2021 / Accepted: 5 October 2021 / Published online: 18 October 2021

(c) The Author(s), under exclusive licence to Springer-Verlag GmbH Germany, part of Springer Nature 2021

\section{Dear Editor,}

Appropriate vaccination remains the most effective approach against contracting the severe acute respiratory syndrome coronavirus 2 infection and the resulting coronavirus disease 2019 (COVID-19) [1, 2]. Although most adverse events due to both adenoviral vector-based (ChAdOx1 nCov-19 and Ad26.COV2.S) and mRNA-based (BNT162b2 mRNA and mRNA-1273) vaccines are tolerable, thrombotic thrombocytopenic purpura (TTP) is a rare but potentially fatal event [3, 4]. Herein, we present the case of a patient with ChAdOx1 nCov-19 vaccine-induced TTP successfully treated with plasmapheresis.

A 75-year-old man experienced bleeding from the tongue 30 days after administration of the ChAdOx 1 nCov-19 vaccine. His initial hemogram revealed leukocytosis (leukocyte count: $9520 / \mu \mathrm{L}$; reference: $4000-8000 / \mu \mathrm{L}$ ), anemia (hemoglobin: $10.5 \mathrm{~g} / \mathrm{dL}$; reference: $13.5-17.5 \mathrm{~g} / \mathrm{dL}$ ), and thrombocytopenia (platelet: $9000 / \mu \mathrm{L}$; reference: $150000-400000 /$ $\mu \mathrm{L})$. Furthermore, increased d-dimer $(2.74 \mathrm{mg} / \mathrm{FEU}$; reference: $<0.55 \mathrm{mg} / \mathrm{FEU})$ and lactate dehydrogenase (1675 IU/L; reference: 120-240 IU/L) levels and decreased haptoglobin $(<0.0781 \mathrm{~g} / \mathrm{L}$; reference: $0.3-2.0 \mathrm{~g} / \mathrm{L})$ levels were noted. Prothrombin time, activated partial thromboplastin

Cheng-Han Wu

wuchen50218@hotmail.com

1 Division of Hematology/Medical Oncology, Department of Medicine, Taichung Veterans General Hospital, Taichung, Taiwan

2 Graduate Institute of Clinical Medicine, College of Medicine, National Taiwan University, Taipei, Taiwan

3 Department of Life Science, Tunghai University, Taichung, Taiwan

4 School of Medicine, Chung Shan Medical University, Taichung, Taiwan

5 College of Medicine, National Chung Hsing University, Taichung, Taiwan time, and fibrinogen level were within normal ranges. To further investigate the possibility of vaccine-induced immune thrombotic thrombocytopenia, we performed the enzyme-linked immunosorbent assay to detect antibodies against the PF4-heparin/complex, which tested negative (optical density: 0.127; reference: <0.400). Multidetector computed tomography did not reveal peripheral vascular or pulmonary artery thrombosis. Autoimmune panel workup was unremarkable. Human immunodeficiency virus, hepatitis B virus, Epstein-Barr virus, and cytomegalovirus all tested negative. However, we found abundant schistocytes on the peripheral blood smear (Fig. 1a), and the ADAMTS-13 activity was only $0.8 \%$ (reference: $40-130 \%$ ). Considering TTP, we initiated plasmapheresis for five consecutive days. Thrombocytopenia substantially improved from 9000 to 235000/ $\mu$ L (Fig. 1b).

Although cases of TTP after various vaccinations have been previously reported [5], the pathophysiology of the ChAdOx1 nCov-19 vaccine-induced TTP remains unclear. Autoantibodies against ADAMTS-13 induced by the ChAdOx1 nCov-19 vaccine could be a potential mechanism [3]. In addition to vaccine-induced immune thrombotic thrombocytopenia [6], TTP needs to be considered in patients presenting with thrombocytopenia after any COVID-19 vaccination. Early diagnosis and plasmapheresis are crucial to prevent mortality in these patients. 

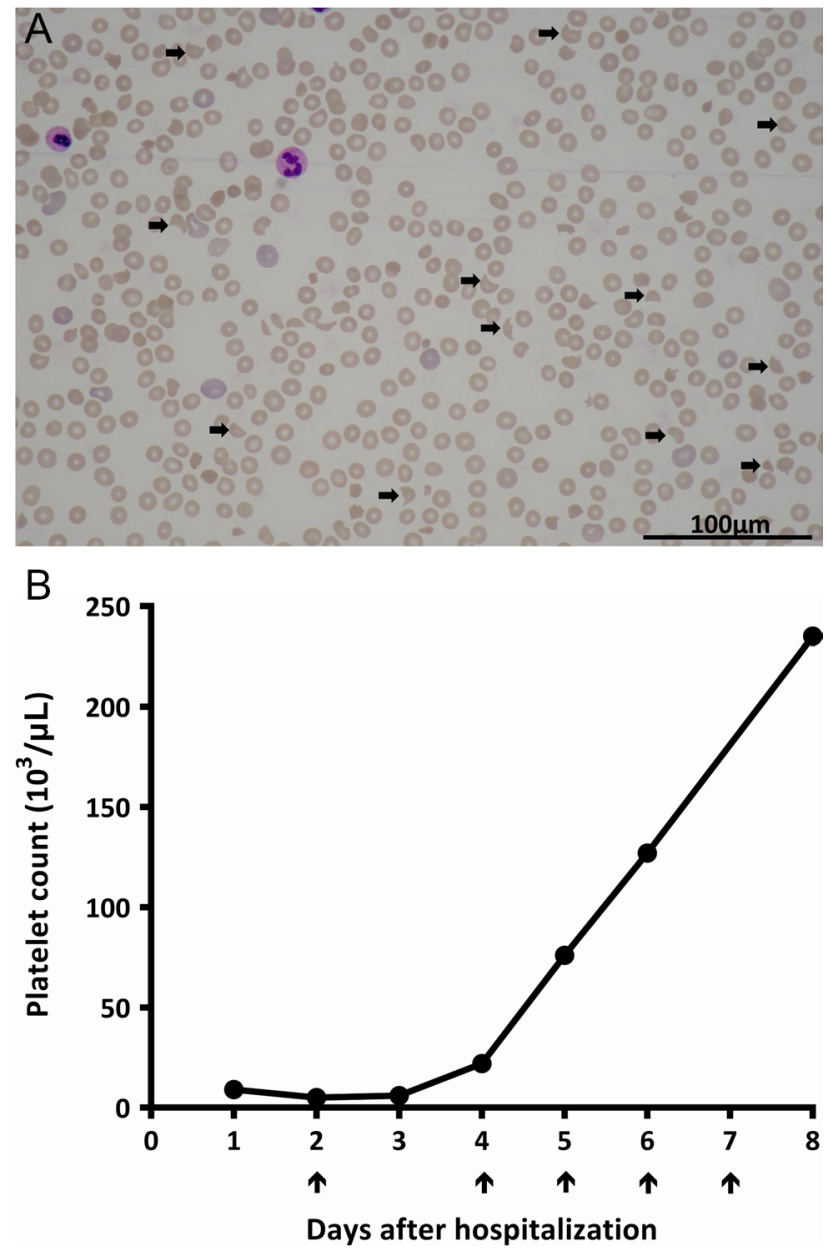

Fig. 1 A Abundant schistocytes on the peripheral blood smear (arrows) (Liu's stain, 400×). B Thrombocytopenia substantially improved from 9000 to $235000 / \mu \mathrm{L}$ after plasmapheresis (arrows)

Funding This study was partially supported by grants from MOST 110-2314-B-075A-005

TCVGH-1103701C.

\section{Declarations}

Ethics approval and consent to participate This study was conducted in accordance with the current version of the Declaration of Helsinki. The institutional review board of the Taichung Veterans General Hospital approved the study and agreed to waive the patient's informed consent due to its retrospective nature (CE21356B).

Conflict of interest Chieh-Lin Jerry Teng received an honorarium and consulting fees from Novartis, Roche, Takeda, Johnson \& Johnson, Amgen, BMS Celgene, Kirin, AbbVie, and MSD. The other authors declare that they have no conflicts of interest.

\section{References}

1. Polack FP, Thomas SJ, Kitchin N, Absalon J, Gurtman A, Lockhart S, Perez JL, Perez Marc G, Moreira ED, Zerbini C, Bailey R, Swanson KA, Roychoudhury S, Koury K, Li P, Kalina WV, Cooper D, Frenck RW Jr, Hammitt LL et al (2020) Safety and efficacy of the BNT162b2 mRNA Covid-19 vaccine. N Engl J Med 383(27):2603-2615. https://doi.org/10.1056/NEJMoa2034 577

2. Voysey M, Clemens SAC, Madhi SA, Weckx LY, Folegatti PM, Aley PK, Angus B, Baillie VL, Barnabas SL, Bhorat QE, Bibi S, Briner C, Cicconi P, Collins AM, Colin-Jones R, Cutland CL, Darton TC, Dheda K, Duncan CJA et al (2021) Safety and efficacy of the ChAdOx1 nCoV-19 vaccine (AZD1222) against SARSCoV-2: an interim analysis of four randomised controlled trials in Brazil, South Africa, and the UK. Lancet 397(10269):99-111. https://doi.org/10.1016/S0140-6736(20)32661-1

3. de Bruijn S, Maes MB, De Waele L, Vanhoorelbeke K, Gadisseur A (2021) First report of a de novo iTTP episode associated with an mRNA-based anti-COVID-19 vaccination. J Thromb Haemost 19(8):2014-2018. https://doi.org/10.1111/jth.15418

4. Yocum A, Simon EL (2021) Thrombotic thrombocytopenic purpura after Ad26.COV2-S Vaccination. Am J Emerg Med. https:// doi.org/10.1016/j.ajem.2021.05.001

5. Yavasoglu I (2020) Vaccination and thrombotic thrombocytopenic purpura. Turk J Haematol 37(3):218-219. https://doi.org/10.4274/ tjh.galenos.2020.2020.0060

6. Tiede A, Sachs UJ, Czwalinna A, Werwitzke S, Bikker R, Krauss JK, Donnerstag F, Weissenborn K, Hoglinger G, Maasoumy B, Wedemeyer H, Ganser A (2021) Prothrombotic immune thrombocytopenia after COVID-19 vaccination. Blood 138(4):350-353. https://doi.org/10.1182/blood.2021011958

Publisher's note Springer Nature remains neutral with regard to jurisdictional claims in published maps and institutional affiliations. 